\title{
6
}

\section{The Child Support Scheme: What innovative collaboration can achieve}

\author{
Meredith Edwards
}

\section{The context and the problem}

This chapter deals with the policy development process for Australia's Child Support Scheme (CSS), focusing particularly on the period 1986-88 but also briefly describing what happened in the subsequent implementation and evaluation phases until the present day. ${ }^{1}$ Poverty among families with children - in particular, sole-parent families-was on the rise in the 1970s. One estimate of the poverty among female-headed sole-parent families suggested an increase from 38 per cent in 1972-73 to 50 per cent in 1981-82 (McClelland 2000: 23). By the time Labor came to power in 1983, it was clear that low-income families were in need

\footnotetext{
1 I am indebted to valuable comments on earlier drafts of this chapter from Kay Cook and the editors of this volume. I was both author of this paper and a participant in the development of the CSS from 1985 to 1988. My roles included: member of the Family Law Council (FLC) and coauthor of the FLC paper referred to in the text; ministerial consultant and head of the Maintenance Secretariat in the Department of Social Security (DSS); and, later, head of the Social Policy Division in the DSS. While my unique position allows me to provide, hopefully, an accurate account of what occurred in the development of the CSS, I have attempted to minimise any bias that might colour my assessment of the scheme's performance by referring to sources that have independently assessed the impact and effectiveness of the scheme's operation and implementation.
} 
of increased financial assistance and that some form of government action was required. However, the new Labor Government also realised it had to rein in government expenditure.

Apart from income support payments from the government to soleparent families, additional payments came to some custodial parents from noncustodial parents in court orders for what were then called child maintenance payments. In 1983, relatively few noncustodial parents actually made payments to custodial parents and, where payments were made, they were at relatively low levels. It seemed as if the court system was deficient in collecting and enforcing maintenance payments.

In the mid-1980s, there was an attempt by the National Maintenance Inquiry to reform the court-based system of child payments (AttorneyGeneral's Department 1984). That reform attempted, but failed, to address the way maintenance payments were assessed and hence left inadequate levels of payment. In addition, since no single government agency was prepared to take on the collection and enforcement functions, the inquiry was forced to recommend the setting up of a separate agency, the cost of which would take away most, if not all, of the savings the reform may otherwise have made. In any case, no benefits were to accrue to sole parents. Hence there was not much public support for this change. Yet the problem of few child support payments at relatively low levels remained.

Concern about sole-parent poverty as well as the growing government deficit led to a policy process around maintenance reform in the mid-1980s through several meetings of an interdepartmental committee (IDC) led by the Department of the Prime Minister and Cabinet (PM\&C). However, the number of options put on the table for ministers to consider made it hard for them to agree on which option to pursue (see also Edwards et al. 2001: 67). Without a possible way forward, at this stage, it seemed that reform of the child maintenance system had reached a dead end.

What lay ahead was an opportunity to explore a more effective route to assess, collect and enforce payments from noncustodial parents - a proposal to use the tax system, which was put on the agenda by the Family Law Council (FLC). As it turned out, the FLC played a pivotal role in the eventual direction of child support reform. A paper presented by three of its members at the Family Law Conference in November 1984 canvassed the novel proposal of using the tax system 
to assess, collect and enforce payments from noncustodial parents based on a formula (Harrison et al. 1984). 'This is thought to be the first occasion upon which these proposals were publicly put forward' (CSEAG 1992: 45). The conference paper formed the basis of the FLC's discussions through 1985, including putting their proposal to the attorney-general in December 1985.

At that time, the proposal looked too radical to be feasible. There were multiple challenges for such a scheme to get off the ground, let alone be sustained, given how sensitive were the issues with which it dealt. First, there were no models anywhere in the world; no country had tried to integrate administrative and court-based systems for collecting payments, let alone using the tax system to administratively assess, collect and enforce payments. Second, there was strong bureaucratic resistance to the proposed scheme; no government agency wanted responsibility for it and scepticism about it even happening remained until the scheme was brought into legislation. Third, the proposal had ramifications across a number of government portfolios that made it harder to drive the reform, especially against such bureaucratic resistance. Finally, no lobby group was pushing for it, even though there was general recognition of the problem. Strong opposition came from lawyers but also social welfare groups, who saw the proposals as concerned mainly with raising revenue for the government.

Relevant in the policy context at this time were favourable institutional arrangements. A major review of social security policies was undertaken from the mid-1980s. One of the main concerns of this review was poverty among those on low incomes-in particular, sole-parent families. It recommended higher payments for low-income families, but the severe budget deficit at the time meant new revenue sources would be needed to support such a proposal. The ministers for social security and finance both had a stake, therefore, in a successful scheme that raised revenue as well as assisted in alleviating child poverty. Revenue from the proposed CSS was seen to provide that source (Edwards et al. 2001: 59). The CSS as a revenue source as well as a scheme to assist sole parents turned out to be the right policy at the right time.

Given the above, the existing system was ripe for reform if the policy design addressed the twin problems of lack of government revenue and child poverty. The eventually successful reforms began in a favourable political environment-Kingdon's (1984) window of opportunity had arrived. This was also an era in Australian public policy when big ideas 
did not scare off political action. What followed was a comprehensive and systematic policy process, including the use of evidence to inform key decisions at several stages.

The intention of the government to undertake major reform in this area was announced by the social security minister Brian Howe on 19 August 1986. The scheme was to be introduced in two stages. Three main elements of reform were introduced under stage one in June 1988: 1) a court assessment of the amount to be paid by the noncustodial parent; 2) the creation of the Child Support Agency (CSA) within the Australian Taxation Office (ATO) to collect payments from noncustodial parents covered by the scheme and, where appropriate, direct monthly payments (or automatic withholding) from wages and salaries; ${ }^{2}$ and 3 ) distribution of the payments to custodial parents monthly by the Department of Social Security (DSS). Stage two began in October 1989 and replaced the stage one court assessment with administrative assessment by the tax system through the CSA as well as introducing a legislative formula related to the taxable income of the noncustodial parent.

The pay-as-you-earn system of collecting taxes would be used to collect child support payments. The CSA had the task of locating noncustodial parents, using the resources of the ATO if necessary (Daniels 1990: 5). The agency was also responsible for debt recovery. The DSS had as its main role to ensure that its pensioners and beneficiaries took reasonable action to obtain maintenance. In the initial scheme, all separated families were included but those not on a pension could, if they wanted, opt out.

\section{A policy success?}

In programmatic terms, the CSS can be considered a success in achieving its main aims: it increased the proportion of children of separated parents who received support and the amount paid and so assisted in reducing

2 The CSA was formed in 1988 as part of the ATO to administer the CSS. In 1998, the CSA was transferred to the Department of Family and Community Services before becoming part of the new Department of Human Services in 2004. The CSA operated largely as a separate agency until July 2008, when a departmental restructure brought its main enabling functions within the department (ANAO 2010: 27). The Department of Human Services has arrangements in place with the ATO to help facilitate accurate assessment as well as collection of parent income, including child support debts (ANAO 2017: 1.6). 
poverty among sole-parent families; and it also increased the revenue for the government, leading to greater fairness for taxpayers (see, for example, MTCS 2005; Parkinson 2007; Smyth et al. 2015).

In August 1989, the Child Support Consultative Group (CSCG) reported favourably on the operation of stage one of the CSS, especially the substantial increase in coverage of sole-parent families receiving support and the amount they were paid. It was less favourable regarding the delays between court orders and payments being made to custodial parents by the CSA (CSCG 1989). An evaluation of the CSS published three years after the start of the scheme and once stage two had been introduced concluded:

The direct successes of the reforms can be readily identified. The average court order has increased from $\$ 26$ per child per week in 1988 to about $\$ 42$ per child per week in 1991 . The average stage two assessment is about $\$ 49$ per child per week. The number of sole parent pensioners now receiving maintenance has increased from $26 \%$ to almost $40 \%$ and is greater for that proportion of the pensioner population who commenced a pension after the scheme started ... The collection rate has increased from at most $34 \%$ in the years before the scheme to $65 \%$ at the present time ... There is also a significant increase in child support payments outside the scheme by private arrangements between the parents.

This result, achieved in such a short time, places Australia well ahead of the position in overseas countries. (CSEAG 1992: iv)

In contrast to most other countries (notably the United Kingdom), the Australian scheme was significant-as well as for the novel approach of using the tax system for assessing, collecting and enforcing payments-for improving on the adequacy of income levels for sole-parent families as well as limiting government expenditure (see, for example, McClelland 2000: 35). This contributed to both policy success and sustainability.

Fourteen years later, the aims of the CSS were still being achieved. According to the 2005 Ministerial Taskforce on Child Support (MTCS 2005: 2): 'To a considerable extent, the Child Support Scheme has achieved the objectives that successive governments have given for it.' Patrick Parkinson (2007: 181), who chaired the MTCS, subsequently said: 'The Fogarty Committee gave to Australia an excellent first generation child support scheme which has served the country well compared to the schemes of other countries. ${ }^{3}$

3 The Fogarty committee is the Child Support Consultative Group (CSCG) chaired by Justice John Fogarty, which produced the 1988 report Child Support: Formula for Australia. 
In terms of political assessment, the CSS rates highly. Both sides of politics considered action was required to improve the old child maintenance system, and the Opposition came in behind Labor to provide bipartisan support for the scheme. One journalist commented at the time that there was a

bipartisan lull in the warfare between Government and Opposition since the Opposition has not had the nerve or the imagination to think of ways of opposing and criticizing a piece of legislation which is designed to benefit children. (Warden 1988: 13)

This was despite opposition from the usually influential Law Council of Australia as well as the lobby group representing noncustodial parents. Assisting the political acceptance was widespread public support for the CSS; a survey commissioned by the government suggested the CSS had the support of 92 per cent of those surveyed (Daniels 1990: 9). The 2005 MTCS report also saw the scheme as 'successful in promoting community acceptance of the idea of child support obligations' (2005: 2).

The policy process around the eventual birth of the CSS was comprehensive, from problem identification to evaluation (discussed in more detail below). It also had a couple of unusual features. One crucial factor in the policy process stands out: ensuring that the ministers as decision-makers discussed and decided on a set of values and other key issues before deciding on the principles to underpin the scheme and more detailed options. In this case, ministers moved systematically from their areas of agreement through to more difficult and contentious issues before getting into detailed options (Edwards et al. 2001: 71-2). For example, whether to use an administrative or a court-based system needed to be argued and decided before dealing with the issue of whether to use a formula. That issue was to be decided before the critical issue of which government agency to use to assess, collect and enforce payments (Edwards et al. 2001: 72).

The other factor was the use of unusual processes, such as the use of external expert lawyers, a problem-solving group of public servants (called 'contacts', from relevant departments) rather than an IDC, a closely involved set of ministers and the lead minister employing a ministerial consultant to drive the bureaucratic side of reform but with that consultant working out of the department rather than the minister's office. 
Over the past 30 years, the CSS has managed to sustain its performance in terms of achieving its main goals in the face of changing circumstances (discussed further below) and has delivered valued social outcomes as well as earning a broad base of public and political support for its achievements. In addition, the innovative feature of using the ATO to assess and collect payments 'paved the way for other policy reforms'-notably, the Higher Education Contribution Scheme (ASSA 2017: 71).

In terms of assessing endurance, the CSS was not without its failings, especially in its administration. Throughout its 30 years of existence it has been plagued by problems with compliance and enforcement, if not fairness issues (see below). This has meant that some sole-parent families in need of support do not receive it (McClelland 2000: 35; Cook 2017). In addition, as early as 1990 , in response to complaints from noncustodial parents about the unfairness of the scheme, the DSS reviewed the potential impact of the CSS on noncustodial parents with moderate incomes who had formed new relationships and parented more children (Daniels 1990: 18). Over time, a changed environment would require the scheme to be adapted to maintain its public support. A key political trade-off to manage over the years to ensure the continued legitimacy of the scheme was between the adequacy of payments for children and the perceived fairness of the treatment of nonresident parents.

\section{Crafting the CSS}

\section{Agents of change}

As indicated, parallel processes occurred in 1984-85 inside and outside government that reignited a focus on the child maintenance (support) issue and helped to shape the reform agenda, including a critical role played by the FLC. The chair of the FLC was Justice John Fogarty-a man who was passionate about child maintenance reform. Initially, he was sceptical about administrative assessment of child support but, fortunately for the CSS, he had changed his mind by 1986 :

I am now persuaded, contrary to my original reaction to this matter, that: (a) the present system is incapable of dealing with the problem and no amount of adaptation of it will meet the problem; (b) a largely administrative rather than legal response to this problem is now called for. (Fogarty 1986) 
Fogarty was invaluable to the scheme's development from its inception well into its implementation. Such stewardship, from a well-recognised and respected judge, assisted in maintaining momentum and agreement across sectors.

Social security minister Howe became aware of the FLC proposal paper and was impressed by it. It was this paper that convinced him he needed to take a leadership role in policy development. The paper had largely adopted the novel proposal canvassed by Professor Irv Garfinkel from the Institute of Poverty Research at the University of Wisconsin in the United States. Professor Garfinkel was the architect of a pilot child support program based on a formula and using the assessment and collection functions of the tax office that was being tested at that time in the State of Wisconsin.

In 1985, I was able to take time out from the public service for a few months and went to The Australian National University (ANU), choosing to tease out further than the FLC paper had done the implications of a formulabased assessment of payments to be collected through the tax system. I delved deeply into key potentially controversial parts of a tax-based policy proposal. Professor Garfinkel was brought to The Australian National University to provide a keynote address at a conference there on child support and, while in Australia, he met the ministers who would form the subcommittee of Cabinet on child maintenance.

By far the most important individual in this story and the key driver of the reform was Howe. Towards the end of 1985, Howe was strategic in how he sold the idea of a Cabinet subcommittee on maintenance to prime minister Hawke. The subcommittee included treasurer Paul Keating, finance minister Peter Walsh, attorney-general Lionel Bowen, the Minister Assisting the Prime Minister on the Status of Women Susan Ryan and the community services minister Don Grimes. Howe also strategically involved others in the process from within and beyond government to support the reforms and contribute to the process-for example, one group he used as a sounding board was a subcommittee of caucus.

Within the DSS, a small group was set up, known as the Maintenance Secretariat, which included highly knowledgeable and committed lawyers brought into the department from outside specifically to work on the child support proposal, as well as an officer seconded from the Department of Finance. The unusual processes adopted by the secretariat turned out to be more appropriate for such a radical initiative than more traditional 
ways of working within the bureaucracy. This is an example of where a policy idea can assist — with the right combination of people and events, as occurred in this case-in moving a policy issue forward.

\section{From problem framing to policy design}

There is one critical stage in a good policy process: the policy problem needs to be clarified, well articulated and then owned by the policymaker(s) and, ultimately, the public. It is only once a policy issue is accepted as a problem that people can ask, 'What can we do about it?'

In the child support reforms, it was relatively easy to articulate the problem: why should kids suffer and taxpayers foot the bill just because parents decided not to live together? The ministerial subcommittee on maintenance, which had announced in August 1986 the principles underlying its proposed reforms, issued a discussion paper the following October called 'Child Support'. Under the section 'Why Reform', the paper said:

There is widespread agreement that Australia's current system of child maintenance is in need of reform. The payment of maintenance is effectively a voluntary act, because those who do not want to pay need not do so, and the amounts that are paid are often low in relation to the non-custodial parent's capacity to pay. In the absence of adequate maintenance, an unfair burden is imposed on the taxpayer. (Cabinet SubCommittee on Maintenance 1986: 6)

Because the policy initiatives were radical, complex, cross-departmental and involved politically sensitive issues, it was important that each of the policy stages was covered in the paper. The first necessary stage, considered above, involved identification and articulation of the problem. Also, as already indicated, before moving into policy analysis and deciding which options to put before ministers, it was important to attempt to understand the values that would frame the options.

The policy process_-far from being a linear one-was like an improvised dance (cf. Althaus et al. 2018: 45). Stages in a policy process may need to be visited in a different order or revisited, and there can be backwards as well as forward movements across stages, or even overlapping stages. In this sense, the process can be seen as iterative. In some cases, it would have been inefficient to backtrack; in other cases, backtracking seemed to be the only way to reach a solution (Edwards 2004: 6). 
An example of backtracking, as described more fully below, was, for political reasons, the phasing in of the scheme in two stages—as a result of successful lobbying and media attention about claimed unintentional consequences of the scheme. The first stage consisted of the more readily acceptable element of the collection of payments, leaving the more contentious formula issues until the second stage and after a review. Identifying the problem can overlap with a policy idea where the policy idea gives momentum to the reform agenda (Edwards 2004: 7). Thus, when Professor Garfinkel met with ministers, he was able to impress them with a policy solution as much as gaining acceptance of the problem. Thus, to generalise: 'The policy dance is sometimes seemingly random movements rather than choreographed order' (Althaus et al. 2018: 52). But, unless each stage is covered, major policy proposals will have less chance of turning into reality.

Few policy issues would have thrown up as many difficult and sensitive issues for analysis as did the child support reforms. As Smyth et al. (2015: 218) write:

[C]hild support policy is an area fraught with high personal emotion. It is typically tempered by a litany of stakeholders, interest groups, anecdotes, and competing interpretations of what's going on ... Value judgments about what constitutes 'fairness', highly technical legislation and policy rules, and complex interactions between child support and other policies ... add additional layers of complexity. It is this mix of technical complexity, raw emotion, and disparate competing interests that makes child support one of the most contested areas of public policy.

Resolving in principle the key value issues helped this process, but nevertheless the policy analysis stage needed to be as rigorous and as comprehensive as possible. Gathering relevant data was an essential part of this process (see, for example, Edwards et al. 2001: 70ff.). There was a widespread and mistaken belief that insufficient revenue would be raised because most noncustodial parents had low incomes. Data from the Australian Bureau of Statistics (ABS) were sought and sophisticated modelling was undertaken of the revenue and distributional implications of the different options. Efficiency, equity and administrative simplicity criteria were used to assess possible formulas-especially: the impact on noncustodial parents (particularly those on low incomes), the possible disincentive effects on work, the extent of administrative simplicity and the financial implications (Edwards et al. 2001: 75-6). 
In the consultation phase of policy development, the degree of participation by stakeholders and, more broadly, the public potentially affected by a possible decision will vary depending on the nature of the issue, its complexity and sensitivity. Processes can be formal or informal, continuous or episodic. Whom to consult, why, when in the policy process and how are a critical set of process issues (see Edwards et al. 2012), as is where good judgement is needed (Beauchamp 2016). A deliberate decision in the child support reform case was to use bilateral meetings with stakeholders but not open those meetings to the public (see Edwards et al. 2001: 77).

The Cabinet Subcommittee on Maintenance's October 1986 discussion paper on child support was the main public consultation document. This outlined the reasons for reform and the issues on which the views of the public would be sought. Importantly, the broad directions of reform-reflecting the key issues the subcommittee had been debating for the past few months-were stated as settled and not open for debate: the legislative formula, automatic withholding of noncustodial parents' payments at source, the use of the tax system to collect payments and the scheme's coverage of nonpensioners and nonbeneficiaries (Cabinet SubCommittee on Maintenance 1986: 14-15). Discussion was sought on many other issues, such as: what type of formula to use, how to take into account the financial circumstances of custodial parents and paternity issues (Cabinet Sub-Committee on Maintenance 1986: 40).

The objectives of the proposed scheme, as set out in the discussion paper, were:

- NCPs [noncustodial parents] should share the cost of supporting their children according to their capacity to pay;

- Adequate support be available for all children of separated parents;

- Commonwealth expenditure be limited to what is necessary to ensure that those needs be met;

- The incentive to work be encouraged; and

- The overall arrangements should be simple, flexible, efficient and respect personal privacy. (Cabinet Sub-Committee on Maintenance 1986: 14)

There was considerable support for the reform proposals (see, for example, Daniels 1990: 1), but there were also some real concerns-for example, from custodial parents about whether this was just a revenue- 
raising scheme for the government and by how much children would benefit; and from noncustodial parents who wanted payments to be conditional on obtaining access to their children. And lawyers wanted a formula to provide some flexibility to determine payments on an individual basis. In response, the Cabinet subcommittee modified its position on several matters, although, importantly, not on the key principles of the scheme.

Ultimately, following refinement of the original proposals, the pivotal stage occurred and policy decisions emerged in what was a highly political context. This was when the political, policy and administrative impacts of the proposal were weighed.

\section{Coming to decisions}

It was not until the formal consultation process with the public had begun, late in 1986, that lobby groups and others realised the government was serious about pursuing reform. The radical policy proposal hit its biggest hurdle early in 1987 when media headlines gave attention to public criticisms from the Law Council of Australia and the likelihood that the government would back off from the reforms. One article in the Australian Financial Review highlighted the Law Council's concerns but also those of the Lone Fathers' Association about the 'unintended consequences' of the scheme-especially the use of a formula, but also whether the income of custodial parents would be taken into account in the formula, how self-employed people would be treated and whether unwed mothers would have to declare the name of the father of their children (Australian Financial Review, 13 January 1987, cited in Edwards et al. 2001). Further, an election was due later that year.

Minister Howe showed great skill at this stage in judging the need for the scheme to be modified and to suggest to his ministerial colleagues that the scheme could be broken up into two stages, as outlined above. Howe did not, however, lose sight of his longer-term vision. The government kept its resolve to have a formula to assess payments through the tax system and, in March 1987, it announced its firm policy (Daniels 1990: 1). To meet concerns, in May 1987, it appointed the CSCG to recommend what that formula would be as well as to monitor the introduction of stage one. 
The CSCG fleshed out administrative aspects of the scheme alongside how the formula could be applied. It presented a unanimous report to the minister in May 1988, prior to the introduction of stage two the following year (Edwards et al. 2001: 79). Of strategic importance was not only the appointment of Justice Fogarty to chair the CSCG, but also appointing community representatives to the group, including a vocal noncustodial parent from the Lone Fathers' Association, Barry Williams. In this way, broad public support for the scheme was achieved and maintained.

\section{Implementing the CSS and its legitimacy in a changing environment}

\section{Early implementation issues}

One hard judgement for a policy advisor or policymaker to make is the ease with which potential policies can be implemented: those responsible for implementing will err on the side of caution; policy people will tend to underestimate the difficulties.

If the views of those charged with implementing the CSS were listened to at the beginning, it is highly likely the novel scheme would not have emerged, although many of the subsequent implementation issues may well have been easier to handle had they been more clearly anticipated as the scheme was being developed. As it transpired, despite sound policy design, implementation of the CSS left a lot to be desired.

Once it was clear from the 1986 budget announcements that the CSS would go ahead, collaboration across departments was required on the detailed policy and legislative issues yet to be resolved. Towards the end of 1986 and well into 1987, several implementation committees were set up to address issues such as property, constitutionality, costing and marketing issues, with different departments chairing different committees. Each committee reported to the whole-of-government 'contacts' group before their papers went into the Cabinet process.

Two key implementation issues emerged in this process. The ATO played the 'resources game' hard with what were considered by the Department of Finance and others to be excessive bids. The second issue was timing: a constant difficulty for the Maintenance Secretariat was getting departments to deliver to agreed but tight timelines. 
It was generally agreed by senior ATO officials that the CSS was poorly implemented in the early days. Tax officers were expected to undergo a major cultural shift in dealing with face-to-face clients who were often distressed. They were largely untrained for the task. The ATO would claim that the original decisions and related resourcing did not take into account the need for more customer focus. Moreover, the system used by the CSA was designed more for tax processes than for a focus on activity at the counter. It was a profound reform that was appended to existing ATO functions rather than integrated into them and that was a large factor in leading to early implementation problems. One ATO officer involved in the development of the CSS remarked:

The scheme had not won the hearts and minds of all the senior people in the Tax Office: the folklore was that 'we were told we had to have it'. I was the eighth person in my position in four or five years, including people just before retirement. It was a time of downsizing and hence there was a chance to transfer staff into the agency. So we could have put more investment into the different skills and attitudes and qualities that people in child support would need and we did not put enough investment into that sort of thing ... We also didn't anticipate enough the cultural shift required. (David Butler, quoted in Edwards et al. 2001: 90)

Not surprisingly, the above factors were reflected in subsequent evaluations and, indeed, the persistence of implementation deficiencies appears to have been the main reason for the considerable scrutiny the CSS received in the 1990s.

\section{Evaluations in the 1990s}

Until the mid-1990s, there were five major evaluation reports over the fewer than seven years of the life of the CSS. This reflects continuing concern about the implementation of the scheme; until this point, most of the changes were administrative rather than major changes to the key policy settings.

Justice Fogarty, as chair of the Child Support Evaluation Advisory Group (CSEAG) in 1990, found:

These reforms seem, even in the relatively short time they have been in operation, to have been largely successful. The legislation, with some minor exceptions, appears to be working satisfactorily. (CSEAG 1990: iv) 
In 1990, the revenue clawback was not as high as expected but was sufficient to offset the administrative costs and stage two (introduced in October 1989) was expected to make a much larger contribution.

The CSEAG reported on the scheme as a whole at the end of 1991 and focused on its significant, if mainly administrative, problems (CSEAG 1992). It also believed it was important to monitor and refine the formula, noting the complaints from noncustodial parents who had second families:

The debate now is not whether child support should be assessed by a formula but whether the formula in Australia is satisfactory or whether it can be improved. The debate now is not whether child support obligations should be enforced through the Taxation Office but whether its procedures need to be improved so as to become more efficient and effective. (CSEAG 1992: iv)

Many administrative refinements were made to the CSS after 1992, with almost continuous evaluation and/or client surveys. Of note was the first parliamentary inquiry into child support: in 1993-94, a joint select committee of parliament inquired into, among other things, 'the operation and effectiveness of the Child Support Scheme' (Parliament of Australia 1994). Although the committee's inquiry was wideranging and identified many problems in the design and operation of the CSS, it recommended the continuation of the scheme. In relation to early implementation issues, the committee noted:

Two issues which were brought to light soon after the creation of the CSA also contributed to the early problems faced by the CSA and still remain unresolved. The first was the incorrect assumption that the CSA would only have minimal contact with its clients. The second issue was that the CSA was unable to handle the increased workload generated by the introduction of Stage 2 of the Scheme. (Parliament of Australia 1994: 92)

Among its 163 recommendations, the select committee called for work to be done to find out why a significant proportion of custodial parents received no child support or did not have child support arrangements. It also recommended a redrafting of the objective of the CSS to put more emphasis on both parents supporting their children according to their respective capacities to pay (taking out the childcare component of the custodial parents' disregarded income), that the child support formula be changed accordingly (Parliament of Australia 1994: xv-xvi) and that noncustodial parents be able to pay privately rather than through automatic withholding (p. xxii). It called for a review in 1996-97 of 
where the CSA should be administratively located, having expressed some concerns about its location within the ATO (Parliament of Australia 1994: xvi-xvii). Finally, it recommended that there be an independent study into the costs of raising children to evaluate the child support formula percentages (Parliament of Australia 1994: xxx). The government responded by accepting the recommendations that had no budgetary implications but putting off remaining ones until the 1996-97 Budget.

The Australian National Audit Office (ANAO) has undertaken efficiency audits of the CSS since its inception. In 1994, for example, it found unresolved administrative problems and 'serious deficiencies in the management and administration of the scheme, a major consequence of which is an unsatisfactory standard of service to clients', indicating that most of the 'administrative shortcomings' identified in the December 1991 CSEAG report remained (ANAO 1994: viii). Reporting four years later, it noted 'significant initiatives to improve on client service and staff development' as well as other improvements identified as lacking in the previous audit (ANAO 1998: xii). It did point out a continuing problem with debt collection and the need for agencies involved with the CSS to clarify their respective roles and responsibilities (ANAO 1998: xiii). In 2009 , it noticed continuing problems in compliance with payments to noncustodial parents and, as late as 2017 , while it assessed the efficiency of the collection arrangements and the administrative framework as 'sound', it recommended improvement, especially to ensure against fraud and tax evasion by noncustodial parents and the creation of a better compliance regime through improved data exchange between the ATO and the Department of Human Services (ANAO 2009).

The many evaluations of the CSS in the 1990s, not surprisingly, focused mainly on administrative deficiencies. But some issues were emerging that would lead to more major policy changes at the beginning of the next century to adapt the CSS to a changed environment in terms of family structures and social values - changes that would impact on the child support formula.

\section{Policy adaptation to a changing environment}

Despite the many reports and reviews into the operations of the CSS from its inception, it was not until 2003 that any substantial policy change began. The prime minister at this time, John Howard, pressured by noncustodial parents, established an inquiry to investigate '[w] hether 
the existing child support formula works fairly for both parents in relation to their care of, and contact with, their children' (Standing Committee on Family and Community Affairs 2003: xvii) and ways for parents to share the care of children post separation, as well as the fairness for parents of the child support formula.

In its report, Every Picture Tells a Story (2003), the Standing Committee on Family and Community Affairs recommended, among other actions, the setting up of the MTCS. The government adopted this as well as the majority of the child support recommendations in whole or in part. It considered proposed changes to the Family Law Act 1975 to recognise

the importance of children having the opportunity for both parents having a meaningful involvement in their lives and will include a new presumption of joint parental responsibility, except in cases involving child abuse or violence. (Commonwealth of Australia 2005: 2)

The taskforce recommended by the standing committee spearheaded a major process of policy change for the next five years. It justified the relatively major changes it recommended to the CSS on the basis of up-to-date evidence on the costs of raising children as well as changes in the circumstances of Australian families and in social security and income distribution policies since the start of the scheme. Moreover, it argued that there was now more emphasis on shared parental responsibility and on both parents remaining active in their children's lives and more mothers in the workforce (for more detail, see MTCS 2005: 2; Parkinson 2007: 180-2).

An independent 'expert' inquiry complemented the work of the MTCS 'to address a perceived "evidence gap"' (Regan 2017: 12-13). Importantly, while much evidence was gathered, especially on the costs of raising children, the evidence used was, as one of the participants in the process observed, 'within the boundaries of the moral imperative and other constraints such as what we knew would be politically acceptable and acceptable to stakeholders' (quoted in Regan 2017: 18). Thus, principles and values informed the evidence and the policy process, including that both parents were responsible for their children. This approach was considered necessary to fulfil the political function of bringing credibility and legitimacy to the findings of the taskforce (Regan 2017: 20). 
The taskforce's report, In the Best Interests of Children (MTCS 2005), recommended major changes to the CSS (Parkinson 2007: 179), especially to the formula used to assess payment levels. It considered that, while the original CSS formula had served the country well, it could no longer be defended in the light of what was now known about the costs of raising children at the beginning of the twenty-first century (Parkinson 2007: 180). It proposed a new set of principles in which the balance was less on 'adequacy' (or sole-parent family poverty) and more on 'equity' between households (MTCS 2005: 117-20; Smyth and Henman 2010: 12).

Analysis by Cook and Natalier (2016: 163) reveals that many more fathers' than mothers' voices were included in the relevant chapter on the voices of parents. The economic modelling in 2008 of the impact of the revised formula and other reforms adopted by the government in response to the MTCS's recommendations showed that child support payments were lower and there was an increase in the proportion of custodial parents at an income disadvantage, although this was not quite as significant three years later (Smyth and Henman 2010; Smyth et al. 2015; Skinner et al. 2017: 89). An evaluation of the reforms concluded: 'Australia may not have made as much progress as it would have liked in this thorny area of social policy-especially in relation to compliance and perceptions of fairness' (Smyth et al. 2015: 217).

The latest review of the CSS, From Conflict to Cooperation: Inquiry into the child support program (Parliament of Australia 2015), occurred in 2014-15 through a parliamentary committee. As with previous reviews, this one concluded that the CSS 'is generally functioning as intended' (Parliament of Australia 2015: 2) and hence the committee's focus was on ways to improve the system for people with child support problems, 'while not disrupting the areas in which the [CSS] is working well' (p. 2).

An interesting suggestion the committee made was to explore the systems overseas that guaranteed child support payments to those parents whose children did not receive payments or received underpayments (Parliament of Australia 2015: 3; see also Cook 2017). This was proposed as part of the original scheme in the 1980 s but fell by the wayside in the 1980 s, partly as a casualty of an election that broke the CSS reform momentum. It is also interesting as an indication that placing the burden on custodial parents to obtain their payments had swung too far and there was a greater role the state could play in reducing sole-parent family poverty (for ways to increase the role of the state, see Cook and Natalier 2015). 
The government accepted most of this report's recommendations, at least in principle, including agreeing to review parts of the child support formula and updating evidence on the costs of raising children. Significantly, it rejected the recommendation for a system of limited guaranteed payment of child support (Commonwealth of Australia 2016). Other than some technical changes, little change to the CSS has so far occurred.

\section{Analysis and concluding reflections}

What were the main factors that led to the introduction of such a radical scheme and its policy endurance? And to what extent might they be replicable to other policy issues? One of the main features of the child support case was the use of a comprehensive approach to developing its policy. Careful attention was paid to the economic and political contexts of the time in identifying and articulating the problem: the poverty of sole-parent families combined with the unfair burden on taxpayers at a time of government fiscal constraint. In this case, the problem was easy to articulate: why should children suffer financially just because their parents had decided to separate; and why should the taxpayer pick up the bill?

There was also constant use of relevant data and evidence to support arguments for reform and how that should progress. Where it was possible, confronting ministers early with key values-based issues helped them clarify their objectives and speed up the policy process. Further, consultation was quite inclusive for the times.

As with so many policies, this case illustrates a policy implementation gap: where the policy process fell down was in the implementation stage, as many subsequent evaluations identified. This reflects, in part, how hard it is to change the culture of an organisation such as the ATO, which was not used to dealing face to face with clients. Also, as this chapter has indicated, a constant theme throughout has been the failure of the CSS to deal satisfactorily with compliance and enforcement issues.

A comprehensive framework of the stages in developing policy is only part of the story if desired policy outcomes are to have a chance to succeed. A common thread in good policy processes (often not given due attention in the theory of policymaking) is giving careful consideration to organisational structures and processes within which policy work occurs. 
A good example in this case is the critical decision taken to introduce the CSS in two stages when it appeared that public support for the proposal was waning (see Edwards et al. 2001).

In addition, there were strong relationships among key players; there was a cohesive network of players, each of whom knew each other across political, policy and non-governmental sectors. Highly knowledgeable and committed lawyers were hired and used effectively to come up with creative solutions. Above all, the policy was spearheaded by a determined and strategically insightful minister, with his ministerial colleagues closely involved, providing the necessary strong leadership.

In sum, the CSS — particularly its use of the ATO—was, and is, generally considered to be an innovative policy initiative in terms of being an effective mechanism for assessing, collecting and enforcing payments from noncustodial parents compared with the previous court-based system. It was the first scheme of its kind in the world. It illustrates how bold reform can happen when there is 'an alignment of political will, a clearly articulated policy problem and social science evidence for reform measures' (ASSA 2017: 70). As Justice Fogarty reflects:

My belief is that social reforms of this sort rarely have a second opportunity. I think you catch one wave to the shore and, if you miss that, then you may wait a very long time before the next wave comes along. It was fortunate that [there was] the conjunction of committed people who were in the right place at the right time. There was a clear vision of what was to occur. It is unusual in a sense that the overall vision was clear ... from 1985 , but the detail of it remained relatively uncertain in some respects until very close to the end of the story. (Fogarty 1995)

Was there a unique set of factors in the CSS case that might not be applicable today or to other policy issues? Certainly, the economic, political and social contexts are very different today. Since the 1990s, there have been many significant changes in the policy environment that make achieving policy proposals that much harder: the great impingement of global forces, the advance of technology in unknown directions, a 24/7 media cycle that allows for ongoing debate over the 'right' policy problem and its solutions, tight budgets not helped by an ageing population, a more networked society, more dispersed power (including to ministerial advisors and non-governmental players), a blurring of boundaries across sectors, citizens less trusting but also more demanding of governments and minority governments becoming more common. Thus, policy outcomes are much more uncertain than in the past. 
In addition, within public services it is now commonly argued that the capability to develop policy and to coordinate responses across government(s) has declined alongside a loss of institutional memory (e.g. Banks 2014a: 14). Also, it can be argued that there is a lack of political courage for a reform that is similar to the CSS in terms of its sensitivity and complexity. Indeed, there has been a lack of necessary courage to tackle reform within the CSS in recent years-witness the 2014-15 inquiry and the government's limited response.

The above factors affecting the policymaking process today are very different from those of the 1980s, but do they make achieving 'reform' so much more challenging? Policy reform may be harder to achieve today for the above reasons, but it is important to realise that most of the fundamental things about a good policy process remain the same and it remains as true today as before that 'good process makes not only for good policy, but ultimately for good politics too' (Banks 2013: 2). 'The fundamental principles of good policy processes should be timeless, even if the manner of their execution must adapt to the times' (Banks 2014b: 42). Now, as then, good policy development requires good analysis combined with an artful mix of process, people and politics.

Currently, despite the rhetoric to the contrary, there is much evidence of a risk-adverse public service environment, with middle management becoming less and not more empowered, so holding back innovative policy initiatives (e.g. Behm 2015: 135-6; Productivity Commission 2017: 198-200). In 2017, the head of PM\&C, Martin Parkinson, implored public servants to break that mould: 'Think big. Aim high. Experiment. Be ruthless. Ask the simple questions if something is not working' (cited in Dennett 2017).

In describing a good policy development process, mention was made above of the importance of confronting ministers early, if possible, with values-based issues before detailed work on possible options occurs. Trade-offs are an inevitable part of making policy. The issue, for example, of the balance to be struck between adequate support for children, on the one hand, and fairness to parents on the other cannot be decided by an IDC or taskforce of officials (on this balance, see, for example, Smyth et al. 2015: 219). That balance has fluctuated over time, for example, with ministers in the 1980s taking a very different view of it than John Howard in his era. The result of his initiated reforms has been a rebalancing of the 'intractable policy problem' between payer, recipient and the needs of government for revenue (see Skinner et al. 2017: 92). 
What will be required for the CSS to remain a success into the future? Community division is a real possibility unless there is courageous leadership. There is a need for a clear articulation by policymakers to the public of the merits of any changes to the CSS, given how contested the issues are between noncustodial parents and custodial parents. And, above all, policymakers will need to ensure any policy changes are implemented as intended.

\section{References}

Academy of the Social Sciences in Australia (ASSA) 2017. The Social Sciences Shape the Nation. Canberra: ASSA.

Althaus, C., Bridgman, P. and Davis, G. 2018. The Australian Policy Handbook. 6th edn. Sydney: Allen \& Unwin.

Attorney-General's Department 1984. A Maintenance Agency for Australia: The report of the National Maintenance Inquiry. Canberra: AGPS.

Australian National Audit Office (ANAO) 1994. Australian Taxation Office: Management of the Child Support Agency. Audit Report No. 39 1993-94. Efficiency Audit. Canberra: ANAO.

Australian National Audit Office (ANAO) 1998. Australian Tax Office: Management of selected functions of the Child Support Agency. Performance Audit. Canberra: ANAO.

Australian National Audit Office (ANAO) 2009. Child support reforms: Stage one of the child support reforms and improving compliance. Performance Audit No. 19 2009-10. Canberra: ANAO.

Australian National Audit Office (ANAO) 2010. Child support reforms: Building a better child support agency. Performance Audit No. 46 2009-10. Canberra: ANAO.

Australian National Audit Office (ANAO) 2017. Child support collection arrangements between the Australian Tax Office and the Department of Human Services. Audit Report No. 50 of 2016-17, 15 May. Canberra: ANAO.

Banks, G. 2013. 'Good processes underpin strong, innovative policy.' Australian Financial Review, 22 March.

Banks, G. 2014a. 'Public inquiries, public policy and the public interest.' In G. Banks, The Governance of Public Policy: Lectures in honour of eminent Australians. Melbourne: ANZSOG. 
Banks, G. 2014b. 'Return of the rent-seeking society.' In G. Banks, The Governance of Public Policy: Lectures in honour of eminent Australians. Melbourne: ANZSOG.

Barratt, G. 1999. Sole parents, income support and family wellbeing. Discussion Paper No. 411. Canberra: Centre for Economic Policy Research, The Australian National University.

Beauchamp, G. 2016. 'The role of government in innovation.' In Institute of Public Administration Australia (ed.), Twelve Speeches 2016: A year of speeches from public service leaders. Canberra: IPAA.

Behm, A. 2015. No, Minister: So you want to be a chief of staff? Melbourne: Melbourne University Publishing.

Cabinet Sub-Committee on Maintenance 1986. Child support: A discussion paper on child maintenance. Parliamentary Paper No. 292, October. Canberra: Parliament of Australia.

Child Support Consultative Group (CSCG) 1988. Child support: Formula for Australia. Report. Canberra: Department of Social Security.

Child Support Consultative Group (CSCG) 1989. The Child Support Scheme: Progress of stage one. August. Canberra: Department of Social Security.

Child Support Evaluation Advisory Group (CSEAG) 1990. The Child Support Scheme: Adequacy of child support and coverage of the sole parent pensioner population. August. Canberra: AGPS.

Child Support Evaluation Advisory Group (CSEAG) 1992. Child Support in Australia: Final report of the evaluation. Volume 1: Main report of the Child Support Scheme. Canberra: Commonwealth of Australia.

Commonwealth of Australia 2005. A new family law system: Government response to Every Picture Tells a Story. Response to the report of the House of Representatives Standing Committee on Family and Community Affairs Inquiry into Child-Custody Arrangements in the event of Family Separation, June. Canberra: Commonwealth of Australia.

Commonwealth of Australia 2016. Australian government response to the House of Representatives Standing Committee on Social Policy and Legal Affairs report: From Conflict to Cooperation-Inquiry into the child support program, August. Canberra: Commonwealth of Australia. 


\section{SUCCESSFUL PUBLIC POLICY}

Cook, K. 2017. The gender of post-separation bureaucracies: A cross-national investigation. Paper presented to third International Conference on Public Policy, Singapore, 28-30 June. Available from: www.ippapublicpolicy.org// file/paper/5937a63a3b020.pdf.

Cook, K. and Natalier, K. 2016. 'Gender and evidence in family law reform: A case study of quantification and anecdote in framing and legitimising the "problems" with child support in Australia.' Feminist Legal Studies 24: 147-67. doi.org/10.1007/s10691-016-9317-9.

Daniels, D. 1990. The child support scheme. Parliamentary Research Service Background Paper, 11 October. Canberra: Department of the Parliamentary Library.

Dennett, H. 2017. 'Get ready for more disruption: Parkinson floats national citizen survey.' The Mandarin, 12 December.

Edwards, M. 2004. Research, social science and public policy: From problem to practice. Occasional Policy Paper No. 2. Canberra: Academy of the Social Sciences.

Edwards, M., Halligan, J., Horrigan, B. and Nicoll, G. 2012. Public Sector Governance in Australia. Canberra: ANU E Press.

Edwards, M., with Howard, C. and Miller, R. 2001. Social Policy, Public Policy: From problem to practice. Sydney: Allen \& Unwin.

Fogarty, J. 1986. Commentary on the paper delivered by Edwards on the Family Law Council's proposals for maintenance reform, June. Unpublished.

Fogarty, J. 1995. Child Support Scheme Seminar. [Recording]. Centre for Public Policy, University of Melbourne, 4 September.

Harrison, M., Harper, P. and Edwards, M. 1984. 'Child support: Public or private?' In Family Law in 84. Volume 2. Canberra: Law Council of Australia.

Kingdon, J. 1984. Agendas, Alternatives and Public Policies. Boston: Little Brown.

McClelland, A. 2000. 'No child ... ': Child poverty in Australia. April. Melbourne: Brotherhood of St Laurence.

Ministerial Taskforce on Child Support (MTCS) 2005. In the Best Interests of Children: Reforming the child support scheme. May. Canberra: AGPS.

Parkinson, P. 2007. 'The future of child support.' University of Western Australia Law Review 33(2): 179-206. 
Parliament of Australia 1994. Child Support Scheme: An examination of the operation and effectiveness of the scheme. Joint Select Committee on Certain Family Law Issues, November. Canberra: AGPS.

Parliament of Australia 2015. From Conflict to Cooperation: Inquiry into the child support program. House Standing Committee on Social Policy and Legal Affairs, July. Canberra: Commonwealth of Australia.

Productivity Commission 2017. Shifting the dial: 5 year productivity review. Report No. 84, August. Canberra: Productivity Commission.

Regan, S. 2017. Inquiring with evidence: How contemporary public inquiries bring evidence to policy. Paper presented to third International Conference on Public Policy, Singapore, 28-30 June. Available from: www.ippapublicpolicy. org//file/paper/593b61b1642ca.pdf.

Skinner, C., Cook, K. and Sinclair, S. 2017. 'The potential of child support to reduce lone mother poverty: Comparing population survey data in Australia and the UK.' Journal of Poverty and Social Justice 25(1): 79-94. doi.org/10.1 332/175982717X14860543256937.

Smyth, B. and Henman, P. 2010. 'The distributional and financial impacts of the new child support system: A "before and day-after reform" comparison of assessed liability.' Journal of Family Studies 16(1)(April): 5-32. doi.org/ 10.5172/jfs.16.1.5.

Smyth, B., Rodgers, B., Son, V. and Vnuk, M. 2015. 'The Australian child support reforms: A critical evaluation.' Australian Journal of Social Issues 50(3): 217-32. doi.org/10.1002/j.1839-4655.2015.tb00347.x.

Standing Committee on Family and Community Affairs 2003. Every Picture Tells a Story: Report on the inquiry into child custody arrangements in the event of family separation. December. Canberra: Parliament of Australia.

Warden, I. 1988. 'Concern for our greatest resource provides a lull in partisan warfare.' The Canberra Times, 18 February. 
This text is taken from Successful Public Policy: Lessons from Australia and New Zealand, edited by Joannah Luetjens, Michael Mintrom and Paul 't Hart, published 2019 by ANU Press, The Australian National University, Canberra, Australia.

doi.org/10.22459/SPP.2019.06 